\title{
The Influence of Quality of Distribution and Sales Promotion to Customer Satisfaction in PT Arasindo
}

\author{
Yusuf Suwandi \\ Soegijapranata Catholic University \\ yusufsuwandi@yahoo.com
}

\begin{abstract}
This study addressed PT Arasindo, a furniture and furniture accessories distributor. It aimed at understanding customers' perception on quality of distribution, sales promotion, and customer satisfaction in PT Arasindo. In particular it was to find out whether the quality of distribution, sales promotions influences customer satisfaction in PT Arasindo. This study used primary data gathered using questionnaire and analyzed using multiple regression analysis. The results show there is influence of the quality of distribution on customer satisfaction.
\end{abstract}

Keywords: quality of distribution, sales promotion, customer satisfaction

\section{INTRODUCTION}

In the competitive business environment, company must be more innovative and has advantages offered to customers and business partners. One concept is business-to-business (B2B) partnership.

This type of partnership can increase efficiency in procurement and more importantly can ease business partner. Business to business (B2B) is a transaction between business institutions. B2B depicts trade transaction between companies, such as between producer and wholesaler, or wholesaler and retailer. It is usually customized according to the need of each partner and this way creates more closed personal relationship between the buyer and the seller in B2B (Kotler and Armstrong, 2001).

Market segment of $\mathrm{B} 2 \mathrm{~B}$ has higher domination in the market because the value of transaction is much higher even though business to consumer (B2C) segment has their own potency. In B2C, customer has higher bargaining position against the conventional seller because customer has variety and detail information. Marketer can choose either B2C or B2B. 
This study focuses on B2B marketing. It is marketing activities involving product (goods or services) selling of a company or organization to another company or organization that emphasize on managing good relationship with the customers (Kotler and Armstrong, 2001).

PT. Arasindo is a furniture and furniture accessories distributor established by Yusuf Suwandi in 2005. PT. Arasindo is located in Jalan Selomas V no.37, Semarang. It sells hinges, latches, handles, furniture accessories, and so on. Its business is B2B since it sells the products to retailers. Its business position is possibly a market follower, meaning it follows the market. Marketing strategy implemented by PT Arasindo is to sell good quality products with competitive sales promotion. It promotes using WOM, personal selling directly to stores. The advantage of its distribution is free delivery costs to the customer's hands. The product is sent in maximum three days (excluding the holidays). The examples of its quality of distribution are that it responds quickly the returned defect product, gives guarantee that the product is unbroken product, delivers the product on time, gives the missing number of product as ordered soon.

Sales promotion programs applied by PT Arasindo are one box free for every 10 boxes bought, cash discount of 1 per cent for cash payment, returnable policy for broken or damage product. Nevertheless, the sales have not increased as expected. Even though it increases each year, but the increase is so small. This becomes an interesting research topic. Following is the sales of PT Arasindo in the year of 2016-2017 (figure 1.). 
The advantage of PT Arasindo is that it has some products with lower price than those of the main competitors as seen in Table 1.

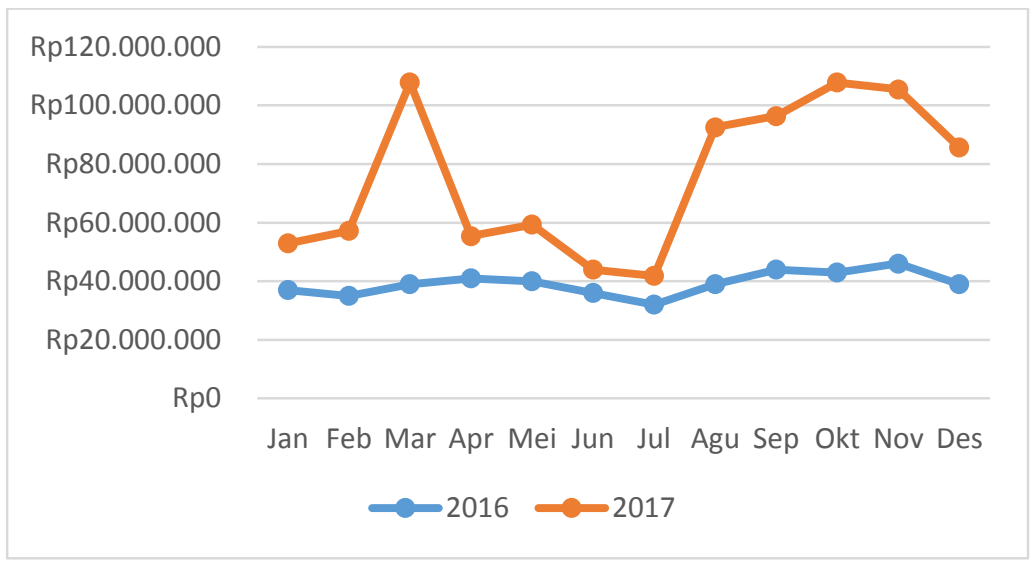

Figure 1. The Sales of PT Arasindo, 2016-2017

Source: Financial Report of PT Arasindo

Table 1. PT Arasindo's Cheaper Products

\begin{tabular}{|c|c|c|c|}
\hline Product & PT Arasindo & PT Mustika & PT Abadi Jaya \\
\hline Sliding Door Reel & $\mathrm{Rp} 153.000$ & Rp 155.000 & - \\
\hline Side Central Lock & Rp 96.000 & $\mathrm{Rp} 101.000$ & $\mathrm{Rp} 98.000$ \\
\hline Lock HL 303 & $\mathrm{Rp} 78.000$ & - & $\mathrm{Rp} 81.000$ \\
\hline Expanded Lock (Kunci Mekar) HL 202 & Rp 55.000 & - & $\mathrm{Rp} 61.000$ \\
\hline Stainless Glass Screw & Rp 32.000 & Rp 33.000 & - \\
\hline
\end{tabular}

Source: PT Arasindo and Competitors, 2018

From Table 2, it is apparent that PT. Arasindo also has problems in the competition. It has some products that are more expensive than its main competitors are. As a result, some of its customers moved to its competitors: PT Mustika and PT Abadi Jaya. This happened because the competitors reduced the price in order to lure the customers of PT Arasindo away. This has been a real competition and can happen to every business.

Table 2. PT Arasindo' More Expensive Products

\begin{tabular}{|l|r|r|r|}
\hline \multicolumn{1}{|c|}{ Product } & PT Arasindo & PT Mustika & PT Abadi Jaya \\
\hline Hinge & $\mathrm{Rp} 5.500$ & $\mathrm{Rp} 5.400$ & $\mathrm{Rp} 5.300$ \\
\hline Latch & $\mathrm{Rp} 10.000$ & $\mathrm{Rp} 9.500$ & $\mathrm{Rp} 9.700$ \\
\hline Drawer Reel & $\mathrm{Rp} 20.000$ & $\mathrm{Rp} 19.000$ & $\mathrm{Rp} 19.500$ \\
\hline Drawer Lock & $\mathrm{Rp} \mathrm{50.000}$ & $\mathrm{Rp} 49.000$ & $\mathrm{Rp} 48.000$ \\
\hline Table Ring & $\mathrm{Rp} 90.000$ & $\mathrm{Rp} 89.000$ & $\mathrm{Rp} 88.000$ \\
\hline Metal Screw & $\mathrm{Rp} 15.000$ & $\mathrm{Rp} 14.000$ & $\mathrm{Rp} 14.500$ \\
\hline
\end{tabular}

Source: PT Arasindo and Competitor, 2018 
Based on the data, it seemingly there is a gap in which PT Arasindo has not been able to acquire new market because of price competition and good relationship of the main competitors with their customers.

The research by Asir (2011) in PT Centa Brasindo Abadi showed that distribution channel, quality of product, and promotional programs influenced customer satisfaction and the first two influenced customer satisfaction through promotional programs.

The research of Salindeho (2014) in PT Frastata Buana Tbk resulted in that quality of distribution and sales promotion had partially significant influence on sales volume.

Another research by Sanjaya (2016) in the case of Aiden conducted B2B concluded that there was an influence of quality of distribution and promotion on satisfaction and sales volume.

Based on the description above, this research focuses on quality of distribution and sales promotion and their influence on B2B customer satisfaction in PT Arasindo. The research problems are defined as follows:

1. How is the customers' perception on quality of distribution, sales promotion, and customer satisfaction of PT Arasindo?

2. How is the influence of quality of distribution on customer satisfaction of PT Arasindo?

3. How is the influence of sales promotion on customer satisfaction of PT Arasindo?

4. How is the influence of quality of distribution and sales promotion on customer satisfaction of PT Arasindo?

Accordingly, the research aims to

1. Understand the customers' responses on quality of distribution, sales promotion, and customer satisfaction of PT Arasindo.

2. Know whether quality of distribution influences customer satisfaction of PT Arasindo. 
3. Know whether sales promotion influences customer satisfaction of PT Arasindo.

4. Know whether quality of distribution and sales promotion influence customer satisfaction of PT Arasindo.

\section{LITERATURE REVIEW}

Distribution is an important factor in delivering product from producer to consumer. Many companies cannot reach their target consumers because of distribution channels that are available less or inappropriate for the company's need. Kotler and Armstrong (2001) stated that distribution channel is a way to distribute goods or services from producer to consumer.

Kotler and Armstrong (2001) outlined two types of distribution channel: direct and indirect distribution channel. Direct distribution channel is distribution of goods or services from producer to consumer with no intermediary. There are four types of direct distribution channel ranging from sales in the production point to sales in retail store.

Sales promotion is every initiative by an organization to promote sales, product usage, or product trial or service (i.e. initiatives not covered by other elements of communication mix or promotion). Sales promotion is a tool of marketing mix to promote product or service by giving incentives or conducting activities such as special offer, discount, coupon, gift, lottery prize, contest, and free sample. Incentive is known as activity or sales promotion and often is used to promote product or service, encourage consumer to make purchase decision or acquisition. Sales promotion is an effective strategy that usually used for launching new product to the market, gaining market share from competitors, or increasing the sales quickly. It however produces cost disadvantage that must be evaluated carefully before applying it (Kotler and Armstrong, 2001).

According to Rangkuti (2001), customer satisfaction is response or reaction on inconformity between expected and actual performance experienced after usage or 
consumption. Tjiptono (2001) stated that customer satisfaction is an individual level of feeling after comparing product performance to their expectation. Consumer satisfaction or dissatisfaction is the response on the evaluation of disconfirmation between expectation and actual performance of the product after usage. Relationship between customers and the company must be in accordance to the expected quality so consumers are satisfying (Tunggal, 1993).

Push and pull strategy is a strategy that can be used to grow the number of consumers. Refering to Kotler and Keller (2009), both strategies are described as follows:

1. Push strategy is active. It is conducted through sales forces, products sold, sales exhibitions, incentive programs to sales forces, and product policy. This strategy is promotion strategy that uses sales force and trade promotion to "push" product through the distribution channel. Producer promotes products to wholesalers, wholesalers to retailers, and retailers promote the products to consumers. The company uses marketing activities (especially sales force and sales promotion) directed to intermediaries to lure them to order and bring the products for promoting to end users.

2. Pull strategy is passive because the growth of consumers is conducted through advertisement and promotion programs in which consumers are expected to be more aware of the product and want to visit one of the company's branches or sales points to be the company's customers. Pull strategy can be Above the Line (ATL) promotion programs, such as those in newspaper, magazine, television, and billboard. It can also be Below the Line (BTL), such as member get member, gathering or event, seminar, and so on. This strategy is promotion strategy that uses a lot of fund for advertisement and consumer promotion in order to gather consumers demand. If pull strategy is successful, consumers will find the product from retailers who will then try to find it from wholesalers, and wholesalers will find from the producer. Pull strategy covers marketing activities (especially advertisement 
and consumer promotion) directed to end users aiming at persuading them to demand the product to intermediaries who will then order the product to the company.

B2B marketing is marketing activity in which a business sells product or service to other businesses for final usage or for selling to other products.

The research framework is as follows:

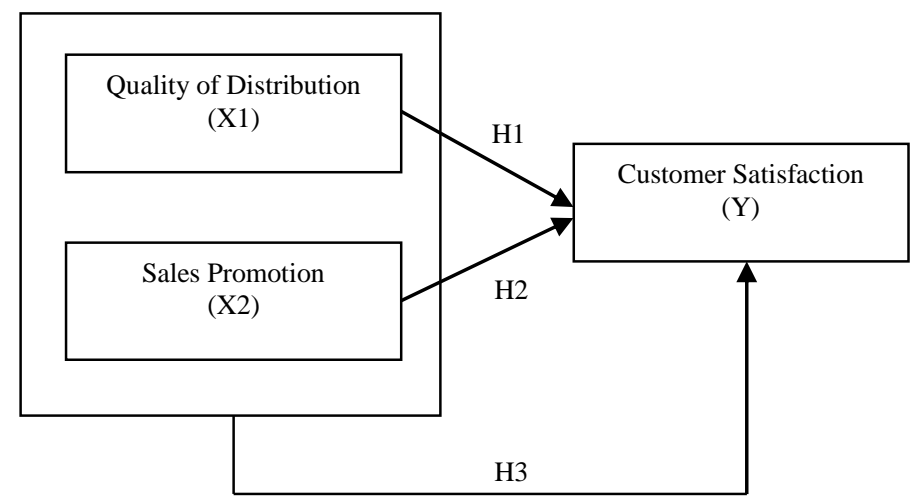

\section{METHODS}

This research was an explanatory research. Sugiyono (2004) stated that explanatory research is a research describing the influence of the researched variables and testing the hypothesis that is the influence of independent variable to dependent variable.

Population is all objects to be researched (Sugiyono, 2004). Population of this research was businesses that were consumers of PT Arasindo amounting of 50 stores. Non-probability sampling applied to select sample was purposive sampling. It was a technique to select sample using particular consideration (Sugiyono, 2004). The criteria for the sample of this research were:

1. The storeowners who have direct interaction with PT Arasindo. They were B2B consumers since they bought the products from PT Arasindo for selling to end users that were industrial consumers.

2. Consumers who bought the products routinely each month during 2017

3. The stores were located in Semarang 
Based on the criteria, there were 40 stores fit with the criteria and the respindents were the storeowners who manage and were involved directly with daily business activities of the store.

This research used primary data gathered using questionnaire. Multiple regression was to analyzed data from the questionnaire in order to know the influence of the independent variables (quality of distribution and sales promotion) on dependent variable (customer satisfaction)..

\section{RESULTS}

\section{Respondents' Perception}

Mean of five statements regarding to quality of distribution was 4.04. It means that the respondents perceived PT Arasindo always helps consumers, provides safe transportation, and delivers on time and in correct numbers. Of the 5 statements, the last one was the highest mean of 4.38. This shows that PT Arasindo sent the products in correct amounts and the company needs to maintain it to make customers satisfy.

\section{Multiple Regression Analysis}

Table 2. Multiple Linear Regression

\begin{tabular}{|c|c|c|c|c|c|c|}
\hline \multicolumn{7}{|c|}{ Coefficients $^{\mathbf{a}}$} \\
\hline \multirow{2}{*}{\multicolumn{2}{|c|}{ Model }} & \multicolumn{2}{|c|}{$\begin{array}{c}\text { Unstandardized } \\
\text { Coefficients }\end{array}$} & \multirow{2}{*}{$\begin{array}{c}\text { Standardized } \\
\text { Coefficients } \\
\text { Beta }\end{array}$} & \multirow[b]{2}{*}{$\mathrm{t}$} & \multirow[b]{2}{*}{ Sig. } \\
\hline & & $\mathrm{B}$ & Std Error & & & \\
\hline 1 & $\begin{array}{l}\text { (Constant) } \\
\text { Quality of } \\
\text { distribution } \\
\text { Sales Promotion }\end{array}$ & $\begin{array}{l}.460 \\
.435 \\
.569\end{array}$ & $\begin{array}{r}1.681 \\
.136 \\
.188\end{array}$ & $\begin{array}{l}.458 \\
.434\end{array}$ & $\begin{array}{r}.274 \\
3.193 \\
3.022\end{array}$ & $\begin{array}{l}.786 \\
.003 \\
.005\end{array}$ \\
\hline
\end{tabular}

a.Dependent Variable: Customer Satisfaction

1. Coefficient regression (beta) for X1 (quality of distribution) was positive meaning the better the quality of distribution, the higher customer satisfaction. 
2. Coefficient regression (beta) for X2 (sales promotion) was positive meaning the better sales promotion increases customer satisfaction.

3. Coefficient regression (beta) for X2 (sales promotion) amounting of 0.569 was the highest. This means that the influence of sales promotion was higher than the influence of quality of distribution. Thus, PT Arasindo should do more sales promotion to increase customer satisfaction.

\section{Testing Hypothesis 1}

Hypothesis 1 in this research is that there is influence of quality of distribution to customer satisfaction. The regression analysis resulted in t value of quality of distribution was 0.003 which is less than 0.05 . The coefficient regression was positive. This means that quality of distribution has influence to customer satisfaction. Thus, hypothesis 1 was accepted. Better quality of distribution will increase customer satisfaction of PT Arasindo. This result supports the previous researches by Wardoyo (2016), Yusuf (2015), and Ariyanto (2009).

\section{Testing Hypothesis 2}

Hypothesis 2 in this research is there is influence of sales promotion on customer satisfaction. The regression analysis resulted in value of $\mathrm{t}$ for the variable of sales promotion was 0.005 , which is less than 0.05 and positive coefficient regression. This means that sales promotion influenced customer satisfaction. Thus, hypothesis 2 was accepted. Better the sales promotion increases satisfaction of the customers of PT Arasindo. This result supports the research of Sofyan (2012) and Sari (2015).

\section{F Test}

Significance value of $\mathrm{F}$ test was $0.000<0.05$ meaning simultaneously quality of distribution and sales promotion influence customer satisfaction. Thus, hypothesis 3 was accepted. 


\section{Coefficient of Determination $\left(\mathbf{R}^{2}\right)$}

Adjusted R Square was 0.696 meaning that variables of quality of distribution and sales promotion contribute $69.6 \%$ to the variance of customer satisfaction and other variables contribute the rest (30.4\%). Thus, PT Arasindo must maintain quality of distribution and sales promotion in considering the competitors.

\section{CONCLUSION}

1. The respondents perceived that it had been easily to contact PT Arasindo even during the out of working hour and it would recall the miss calls. It helped customers' problem in for example, it responded quickly to the defect product returned to it. It used safety transportation system in delivery so the products were free from rain and unbroken, delivered the product on time (in maximum three days the products reached the customer), and sent the product in correct amount as ordered (the company replaced the missing amount as soon as it was found out).

2. PT Arasindo gave discount in its sales promotion in the amount as expected by the customer (buy ten boxes gets one free box, cash discount for those who paid in cash), created interesting advertisements (product catalog and sample were available), and used social media (WhatsApp, BBM, email) for promotion.

3. Customers were satisfied with the sales promotion (in either cash or installment sales promotion) paid by PT Arasindo. They were also satisfied with quality of distribution (on time delivery and guarantee on product condition upon accepted by the customer). They recommended PT Arasindo to others (very often the company got new customers based on recommendation of the existing customers), mentioned the positive things about PT Arasindo (even though some critics were addressed to the company, they could be solved 
quickly) and were insensitive toward sales promotion of the company (understood the factors influencing price increase).

\section{REFERENCES}

Ariyanto, Dimas Is. 2009. Analisis Kualitas Produk, Kualitas Pelayanan, Saluran distribusi dalam Meningkatkan Kepuasan Konsumen Member Amway di Kota Semarang (Studi pada Konsumen yang memakai Produk Amway di Kota Semarang). Universitas Semarang. https://lib.unnes.ac.id/2837/

Asir, Muhammad. 2014. Pengaruh Saluran distribusi, Kualitas Produk Dan Kebijakan Promosi penjualan Terhadap Kepuasaan Pelanggan (Studi Kasus PT. Centa Brasindo Abadi). Jurnal Universitas Hasanudin, Vol $2, \quad$ Nol. http://pasca.unhas.ac.id/jurnal/files/ab04e5b07426daa500ff04740a405335.pdf

Kotler, Philip and Gary Armstrong. 2001. Prinsip-prinsip Pemasaran. Edisi. 8. Jilid 1. Jakarta: Erlangga.

Kotler, Philip and Gary Armstrong. 2001. Prinsip-prinsip Pemasaran. Edisi. 8. Jilid 2. Jakarta: Erlangga.

Kotler, Philip and Kevin Lane Keller. 2009. Manajemen Pemasaran. Jakarta: Erlangga.

Rangkuti, Freddy. 2001. Analisis SWOT: Teknik Membedah Kasus Bisnis. Jakarta :PT. Gramedia Pustaka Utama.

Salindeho, Hanny Aristanto. 2014. Pengaruh Saluran distribusi Dan Promosi penjualan Terhadap Peningkatan Volume Penjualan Pada PT Fastrata Buana, Tbk. Jurnal Ilmu \& $\begin{array}{lllllll}\text { Riset } & \text { Manajemen } & \text { Vol. } & 3 & \text { No. } & 9 & \text { (2014). }\end{array}$ http://karyailmiah.unisba.ac.id/index.php/manajemen/article/view/5165

Sanjaya, Antonio Tirta. 2016. Perancangan Distribution Mix guna Meningkatkan Penjualan Aiden https://journal.uc.ac.id/index.php/performa/article/download/102/95

Sari, Dini Hanim Chandra Puspita. 2015. Pengaruh Promosi penjualan, Distribusi dan Promosi terhadap Peningkatan Volume Penjualan Produk Toyota Nasmoco di Surakarta. http://eprints.ums.ac.id/39085/1/naskah\%20publikasi.pdf

Sofyan, H.K R. Achmad. 2012. Pengaruh Kualitas Produk, Promosi penjualan, Promosi dan Saluran distribusi terhadap Keputusan Pembelian dan Kepuasan Konsumen Laptop Toshiba di Kota Jember. https://media.neliti.com/media/publications/106452-IDpengaruh-kualitas-produk-dan-promosi-ter.pdf

Sugiyono. 2004. Metode Penelitian Bisnis. Bandung: CV Alfabeta.

Tjiptono, Fandy. 2001. Manajemen Jasa. Yogyakarta: Andi Offset.

Tunggal, Amin Widjaja. 1993. Manajemen Mutu Terpadu. Jakarta: Rineka Cipta. 
Wardoyo, Dwityas Adi Kusumo dan Saryadi, 2016. Pengaruh Kualitas Produk, Promosi penjualan, dan Saluran distribusi terhadap Loyalitas Pelanggan Majalah Swa Melalui Variabel Kepuasan Pelanggan (Studi Kasus pada Pelanggan Majalah Swa di DKI Jakarta). Universitas Diponegoro, Semarang. https://media.neliti.com/media/publications/136946-ID-pengaruh-kualitas-produkharga-dan-salur.pdf

Yusuf, Mohammad. 2015. Pengaruh Kualitas Produk, Kebijakan Promosi penjualan, dan Saluran distribusi terhadap Kepuasan Konsumen Pembelian Sperpart Variasi dan Pemasangan di CV. Prima AC. https://media.neliti.com/media/publications/106211-IDpengaruh-promosi-dan-kualitas-produk-ter.pdf 